\title{
Natural and Sustainable Alternative for the Management of Dengue Fever in West Africa
}

\author{
Amodu B ${ }^{1}$, Itodo S.E ${ }^{2}$, Musa, D.E ${ }^{3}$ \\ ${ }^{1}$ Halamin Herbal centre, 10 George Innih Crescent, Apo District, Abuja Nigeria \\ ${ }^{2}$ Department of Histopathology and Cytology, Jos University Teaching Hospital (JUTH) Jos Nigeria \\ ${ }^{3}$ Halamin Herbal centre, 10 George Innih Crescent, Apo District, Abuja Nigeria
}

\begin{abstract}
Dengue fever is a dangerous disease for population which implies high expenses in terms of hospital treatment. With the advent of secularization in form of concoctions infused from cocktails of fruits, vegetables, roots, barks, nuts,etc with the major bioactive constituents of medicinal plants, dengue fever patients were able to normalize their haematological indices and improve their health status dramatically. The patients were divided into three groups. The first one (10) had DAABS-2, the second one (12) had DAABS-2 and the third one (15) had DAABS-2. Ages were around 0-16, 20-29 and 50-69 with prevalence in male which occurred more frequently among the children.
\end{abstract}

\section{Introduction}

Dengue, also known as breakbone fever, is a painful and sometimes fatal viral disease characterized by headache, skin rash and debilitating muscle and joint pains. In some cases, it can lead to circulatory failure, shock, coma and death.

Dengue fever is caused by one of four related, but distinct, virus serotypes (DEN 1-4), which are transmitted to humans by the Aedesaegypti mosquito. Infected humans are the main carriers and multipliers of the virus, serving as a source of the virus for uninfected mosquitoes. The disease is concentrated in urban and peri-urban environments in tropical and subtropical regions.

While at first dengue infection may be asymptomatic, individuals who have been infected with dengue once are more likely to contract severe dengue, which can lead to hemorrhage, shock, coma and death. Though early and effective fluid intake and electrolyte replacement can ease symptoms, it is being postulated that there is no specific medication or cure available for dengue. Without proper treatment of symptoms, such as the fluid intake described above, fatality rates of the severe forms can exceed $20 \%$.

Water containers, flower pots, old automobile tires, buckets and other discarded items that collect rainwater common in urban areas - are the ideal breeding locations for mosquitoes that transmit dengue. Dengue prevention efforts to date have focused on vector control, through emptying of such containers and insecticide spraying.

Outbreaks of dengue fever have occurred recently in the Caribbean, including Puerto Rico, the U.S. Virgin Islands, Cuba, and in Paraguay in South America, and Costa Rica in Central America.

Because dengue fever is caused by a virus, it is said that there is no specific medicine or antibiotic to treat it. For typical dengue fever, the treatment is purely concerned with relief of the symptoms (symptomatic).

The acute phase of the illness with fever and myalgias lasts about one to two weeks.

Dengue hemorrhagic fever (DHF) is a specific syndrome that tends to affect children under 10 years of age. It causes abdominal pain, hemorrhage (bleeding), and circulatory collapse (shock).

The prevention of dengue fever requires control or eradication of the mosquitoes carrying the virus that causes dengue.

While it is being postulated that there are no specific anti-viral tablets or injections that can kill the virus, the immune system can however be stimulated by a high class concoctions infused from cocktails of fruits, barks, roots, stems etc with the major bioactive constituents of medicinal plants to kill the virus This high class concoction has been scientifically formulated into capsules with different strength. One of the high class formulations is called DAABS-2. The constituents of DAABS-2 include Vernonia amygdalina, Dioscorea alata $\mathrm{L}$ and Zea mays. The medicinal uses of the constituents of DAABS-2 are well documented in literature (Dalziel 1937).

But like most traditional medicines in Africa, little or no scientific information is available on this polyherbal component preparation that is akin to the Chinese traditional medicine (TCM) or the India Ayurvedic preparation.

These active constituents are believed to strengthen the immune system through many cytokines and chemokines regulations. With the abundant presence of tannins, phlobatannins, flavonoids, steroids, terpenoids, saponins and cardiac glycosides, which are the most important bioactive constituents of medicinal plants, the 
poly herbal preparation is able to normalize appropriately all the haematological indices and improve health status dramatically.

Vaccines are being developed against all 4 serotypes of dengue fever and they will definitely be the most effective way to prevent the disease. Prevention of mosquito breeding has by and large failed in most endemic countries. Patients are prone to dehydration hence they should drink plenty of fluids. If necessary a few days of intravenous fluids can be administered in the form of normal saline or dextrose saline. This study is therefore designed to determine the clinical activities of DAABS-2- on dengue fever and to create awareness to the public and other healthcare workers on the importance of preventing the breeding site of mosquitoes.

\section{Materials And Methods}

STUDY POPULATION: Study population was made of suspected cases of dengue Haemorrhagic fever clients within the age bracket of 0 month to 69years, that came to seek medical attention in Halamin Chemicals Nigeria Limited Centre, Abuja from April, 2012 to February 2013.Suspected cases comprised of clients that presented with fever and any of the following: headache, pain behind the eye and in muscles and joints enlarged lymph glands, and a maculopapular rash. Sometimes abdominal pain with vomiting and occasionally haemorrhagic symptoms.

DATA COLLECTION: Social-demographic data including age, sex, presenting complaints, relevant signs elicited and orthodox drugs pre-treatment were obtained from the clients.

SPECIMEN COLLECTION: After obtaining the relevant information and explaining to the clients the test procedures, $2 \mathrm{ml}$ of blood was collected aseptically through venepuncture using sterile syringe and needle following application of tourniquet. The surface of the skin was disinfected with methylated spirit on cotton wool and allowed to dry. The blood was transferred to a plain container and allowed to clot at room temperature. The clot was dislodged and centrifuged at 1000rpm for 5 minutes. The serum was harvested using a Pasteur pipette and transferred into serum containers with caps and properly labeled. The test was performed immediately, unless stated otherwise in which case, the samples were kept frozen.

The PCV test was done using the microhaematocrit centrifuge. The platelet count, total white blood cells count and differential, aspartate aminotranferase, blood urea and serum sodium and albumin were carried out in accordance with procedures specified by Monical Cheesbrough (District Laboratory practice in tropical countries, part 2)

\section{Results}

The results of the findings of dengue haemorrhagic fever clients show that nearly all age groups are affected. However, it was observed that the highest occurrence of positive cases was recorded within the age groups of 0-16, 20-29 and 50-69. All age groups were infected with the disease.

Table 1: According to age of client (0-16) that took the supplements $1000 \mathrm{mg} 12$ hourly for 12 weeks

$\begin{array}{ll}\text { PARAMETER } & \text { MONTH } 0 \\ \text { HAEMOGLOBIN } & 48 \mathrm{~g} / \mathrm{dL} \\ \text { PLATELETS } & 50 \times 10^{9} \mathrm{cells} / \mathrm{L} \\ \text { WBC } & 1.0 \times 10^{9} \mathrm{cell} / \mathrm{L} \\ \text { AST } & 170 \mathrm{uL} \\ \text { BLOOD UREA } & 30.2 \mathrm{mmol} / 1 \\ \text { SERUM NA } & 200 \mathrm{mmol} / 1 \\ \text { ALBUMIN } & 5.6 \mathrm{~g} / \mathrm{dL}\end{array}$

$\begin{array}{ll}\text { MONTH } 1 & \text { MONTH2 } \\ 24 \mathrm{~g} / \mathrm{dL} & 12 \mathrm{~g} / \mathrm{dL} \\ 150 \times 10^{9} \mathrm{cells} / \mathrm{L} & 400 \times 10^{9} \text { cells/L } \\ 8.0 \times 10^{9} \text { cells } / \mathrm{L} & 10.0 \times 10^{9} \text { cells/L } \\ 80 \mathrm{uL} & 28 \mathrm{uL} \\ 8.2 \mathrm{mmol} / 1 & 3.0 \mathrm{mmol} / 1 \\ 40 \mathrm{mmol} / 1 & 20 \mathrm{mmol} / 1 \\ 4.0 \mathrm{~g} / \mathrm{dL} & 3.5 \mathrm{~g} / \mathrm{dL}\end{array}$

Table 2: According to age of client 20-29) that took the supplements $1000 \mathrm{mg} 12$ hourly for 12 weeks

\begin{tabular}{llll}
\hline PARAMETER & MONTH 0 & MONTH 1 & MONTH 2 \\
\hline HAEMOGLOBIN & $72.0 \mathrm{~g} / \mathrm{dL}$ & $36.0 \mathrm{~g} / \mathrm{dL}$ & $17 \mathrm{~g} / \mathrm{dL}$ \\
PLATELETS & $50 \times 10^{9} \mathrm{cells} / \mathrm{L}$ & $150 \times 10^{9} \mathrm{cells} / \mathrm{L}$ & $300 \times 10^{9} \mathrm{cells} / \mathrm{L}$ \\
WBC & $2.0 \times 10^{9} \mathrm{cell} / \mathrm{L}$ & $7.0 \times 10^{9} \mathrm{cells} / \mathrm{L}$ & $11.0 \times 10^{9} \mathrm{cells} / \mathrm{L}$ \\
AST & $140 \mathrm{uL}$ & $40 \mathrm{uL}$ & $12 \mathrm{uL}$ \\
BLOOD UREA & $25.6 \mathrm{mmol} / 1$ & $6.4 \mathrm{mmol} / 1$ & $3.5 \mathrm{mmol} / 1$ \\
SERUM NA & $240 \mathrm{mmol} / \mathrm{l}$ & $60 \mathrm{mmol} / 1$ & $40 \mathrm{mmol} / 1$ \\
ALBUMIN & $3.7 \mathrm{~g} / \mathrm{dL}$ & $4.0 \mathrm{~g} / \mathrm{dL}$ & $5.6 \mathrm{~g} / \mathrm{dL}$
\end{tabular}


Table 3: According to age of client (50-69) that took the supplements $1000 \mathrm{mg} 12$ hourly for 12 weeks

\begin{tabular}{|c|c|c|c|c|}
\hline PARAMETER & MONTH 0 & MONTH 1 & MONTH 2 & \\
\hline HAEMOGLOBIN & $48 \mathrm{~g} / \mathrm{dL}$ & $24 \mathrm{~g} / \mathrm{dL}$ & & $12 \mathrm{~g} / \mathrm{dL}$ \\
\hline PLATELETS & $50 \times 10^{9}$ cells $/ \mathrm{L}$ & $150 \times 10^{9}$ cells $/ \mathrm{L}$ & $400 \times 10^{9}$ cells $/ L$ & \\
\hline WBC & $1.0 \times 10^{9} \mathrm{cell} / \mathrm{L} / \mathrm{L}$ & $8.8 \times 10^{9}$ cells $/ \mathrm{L}$ & $10.0 \times 10^{9}$ cells $/ \mathrm{L}$ & \\
\hline AST & $170 \mathrm{u} / \mathrm{L}$ & $70.0 \mathrm{uL}$ & $24 \mathrm{u} / \mathrm{L}$ & \\
\hline BLOOD UREA & $30.2 \mathrm{mmol} / 1$ & $8.2 \mathrm{mmol} / 1$ & $2.5 \mathrm{mmol} / 1$ & \\
\hline SERUM NA & $200 \mathrm{mmol} / \mathrm{L}$ & $40 \mathrm{mmol} / \mathrm{L}$ & $20 \mathrm{mmol} / \mathrm{L}$ & \\
\hline ALBUMIN & $5.6 \mathrm{~g} / \mathrm{dL}$ & $4.0 \mathrm{~g} / \mathrm{dL}$ & $3.5 \mathrm{~g} / \mathrm{dL}$ & \\
\hline
\end{tabular}

The administration of the supplements lasted for 12 weeks. Tables 1,2 and 3 clients were given the DAABS-2 supplement 1000mg twelve hourly for 1 month. The hemoglobin, platelets, WBC, AST, blood urea, serum sodium and albumin were measured before the commencement of the supplement. The measurements were further taken at four weeks interval for two consecutive times.

EIGHT AND TWEFTH WEEK SUBSEQUENT ADMINISTRATION OF DAABS 2

The group A (Table 1) clients showed a remarkable moderation of the haemoglobin level, platelets, AST, WBC, serum sodium, albumin and blood urea from the astronomical heights of the parameters. The group B (TableII) clients were not equally left out from remarkale moderation of the parameter. Group C (Table III) like group A showed similar moderation of the parameters

\section{Discussion}

$\mathrm{T}$ here was a remarkable moderation of the haemoglobin level of $48 \mathrm{~g} / \mathrm{dL}$ which is a clear characteristic of dengue haemorrhagic fever, to a normal level of $12 \mathrm{~g} / \mathrm{dL}$ in group A clients. This remarkable moderation happened through a period of 12 weeks of the administration of DAABS-2 supplements believed to strengthen the immune system and adaptogenized the generality of the human systems. Another unique addendum was the general wellbeing experienced by the clients, the initial complaints of generalized pain, headache, malaise etc. previously noticed by the clients disappeared before the end of the three month. There were equally palpable moderation of the aspartateaminotranferase and total white blood cell count from $170 \mathrm{uL}$ to $28 \mathrm{uL}$ and $1.0 \times 10^{9}$ cells/L to $10.0 \times 10^{9}$ cells/L respectively within the three months use of the DAABS- 2 supplements.

In group Bclients that were mostly adults, it was observed among the client despite the fact that they were reactive to IgM of the dengue virus. However, there was also a remarkable moderation of all the parameters and general improvement in their health status.

The group C clients, like the group A had an astronomical abnormalities in the Haemoglobin, aspartateaminotranferase, serum sodium, total white blood cell count, albumin and blood urea. This is a clear case of dengue haemorrhagic fever as the clients tested positive to IgG of the degue virus. Nevertheless, the clients observed complete restoration of health status even before the completion of the DAABS-2 medicaments at the twelfth weeks set for the observation. It should be noted that no such work has been carried out before, this is the first of its kind.

\section{CONCLUSION}

DAABS-2 with Vernoniaamygdalina as it active ingredient had been used in traditional medicine for the treatment of various ailments (Igileet al., 2004), it has been used to treat gastrointestinal disorders, haematoma, malaria, inflammation, cancer etc. The methanolic extract of the leaves was investigated on the some of the haematological indices. DAABS-2 was able to regularize all the haematological indices and introduced a normalcy in the health status of the clients. Sequel to this finding, it is pertinent that DAABS-2 should be strongly recommended for the management of dengue fever. 